Ioana-Celina Pasca, Ph.D.

West University of Timişoara, Romania

\title{
CRIMINAL PROTECTION OF PRIVACY IN LEGISLATION OF ROMANIA
}

\begin{abstract}
Summary
Increased protection of privacy is a recent concern of Romanian criminal law in the context of the ECHR decisions sanctioning the insufficient protection of the right to privacy.

The new Romanian Penal Code, in force since 2014, provides for a series of offenses without correspondence in the previous penal codes, aimed to protect both against the interference with a person's private life by photographing, capturing images or registering the person and disseminating the information thus obtained, as well as against the interference with someone's professional activity by violating their professional secrecy.

The Romanian legislator also set up, starting with 2018, another means of protecting privacy, namely, a provisional protection order, which may be issued by the police, in the absence of a criminal trial, with respect to a person involved in acts of domestic violence.
\end{abstract}

Keywords: violation of privacy, violation of the professional office, protection of privacy, E.C.H.R.

\section{Introduction}

Efficient protection of privacy constitutes a recent concern of the Romanian legislator, in the sense of ensuring the necessary legal framework in order to defend the values guaranteed by Article 8 of the European Convention on Human Rights, the catalyst being represented by some Decisions of the E.C.H.R. whereby Romania was sanctioned for insufficient protection of the right to privacy.

The new Romanian Penal Code, adopted by Law No. $286 / 2009^{2}$, in force as of February 1, 2014, stands out with incriminations, which represent an absolute novelty for the Romanian criminal law and reconfigures the existing incriminations, in accordance with the provisions of international conventions. However, a few years ago, the Romanian legislator rather easily gave up incriminations such as insult and slander ${ }^{3}$, crimes that provided a greater protection of privacy, although, as it was considered, the verbal or written manner of expression also entails responsibilities,

E.C.H.R., Judgment of 19 November 2013 in the case Ulariu v. Romania (application No. 19267/05, pt. 49).

2 Published in the Official Journal No. 510 of 24 July 2009.

3 Insult and slander were abolished by means of Law No. 278/2006 regarding the modification and completion of the Penal Code. Official Journal, Part I, No. 601 of 12 July 2006. 
and, "in order to avoid insult in its purest form, the one who expresses his/her ideas must manifest a certain prudence in certain sensitive areas in the social context in which they are carried out".

The present article analyses the limits of the violation of the right to privacy through the prism of the new regulations encompassed in the Romanian Penal Code, such as the violation of private life ${ }^{5}$, the violation of professional headquarters ${ }^{6}$, harassment ${ }^{7}$, but also through reformulated incriminations already existing in the previous Romanian Penal Codes, such as the violation of domicile or the disclosure of the professional secret. The latter regulations were found in the previous Penal Code under the chapter entitled "Offenses against the freedom of the person", along with offenses such as illegal deprivation of liberty, threat or blackmail.

Harassment, an offense new to Romanian law, was not included by the legislator into the category of offenses affecting the domicile and private life, but instead in the category of offenses against a person's freedom. Nevertheless, we consider that it is necessary to examine it along with the other offenses, which affect one's domicile and private life, in terms of its ways of incrimination, the offense of harassment affecting not only the freedom of the person, but also their private life.

As of 2018, the Romanian legislator has established another means of protecting private life, respectively, a provisional order of protection that can be issued by police bodies in the absence of a criminal trial, regarding a person involved in acts of domestic violence.

\section{Violation of privacy}

The violation of privacy represents a new regulation, aimed at counteracting the new forms of harm or endangering social values, which have emerged with the evolution of technology. Until the adoption of the new Penal Code, there was no regulation in the Romanian criminal law that sanctioned the interference within private life by means of photographing, filming a person, presenting or transmitting, without the consent of the concerned subject, the conversations or images captured.

Beyond the need to protect the interference within a person's private life by denigration in various forms, the regulation of the offense pertaining to violation of privacy was all the more necessary, since in 2006 insult and slander were disincriminated ${ }^{8}$. From the repeal of the two offenses back in 2006, until the entry

4 Chiriță R. Convenția europeană a drepturilor omului. Comentarii şi explicaţii, [European Convention on Human Rights. Commentaries and explanations]. Vol. II, C. H. Beck, 2007, p. 173.

5 Article 226 Penal Code.

6 Article 225 Penal Code.

7 Article 208 Penal Code.

8 Abolished by Law No. 278/2006 regarding the modification and completion of the Penal Code. Official Journal, Part I, No. 601 of 12 July 2006. 
into force of the new Penal Code in 2014, the dignity, honour and reputation of persons have not benefited from any other form of real and adequate legal protection.

According to Article 226 of the Penal Code, the violation of privacy consists of the unlawful violation of privacy, by photographing, capturing or recording images, by listening using technical means or by recording audio of an individual, in a dwelling or room or outbuilding related to them or to a private conversation.

The legislator also incriminates aggravating variants of the same offense:

the unlawful disclosure, dissemination, presentation or transmission of sounds, conversations or images to another person or to the general public ${ }^{9}$,

but also

unlawfully installing technical means for audio or video recording ${ }^{10}$.

The provisions of Article 226 of the Penal Code expressly stipulate that invasion of privacy is committed by photographing or recording of a person's private life in a dwelling or room or outbuilding related to them. In this case, photographing a person in a car does not meet the constitutive elements of the offense of violation of privacy.

The High Court of Cassation and Justice has shown that the notion of dwelling is identified with that particular space where the injured person lives even temporarily, including a hotel room or a temporary shelter ${ }^{11}$. Intimacy cannot be restricted exclusively to a person's dwelling, "but must be extended to any place where one person reasonably expects not to be seen by others. ${ }^{12}$ "

The offense can also be committed outside a dwelling, when the recording concerns a private conversation. Essential for this offense is the existence of a direct contact among the persons participating in the conversation, otherwise the deed will be qualified as containing the elements of another offense, namely, the violation of the secret of correspondence.

In order to establish this offense, the legislator requires that the photographing or capturing of images be done "without right", that is, without the consent of the person caught in the images. As concerns the phrase "without right", the specialized literature expressed the opinion that it does not constitute an offense to photograph or record a person with his or her express or even presumed

9 Article 226 pt. 2 Penal Code.

10 Article 226 pt. 5 Penal Code.

11 Constitutional Court of Romania, Decision No. 33/2017 regarding the rejection of the challenge of unconstitutionality of the provisions of Article 226 para. (1) of the Penal Code. Official Journal, Part I, No. 320 of 4 May 2017.

12 Slăvoiu R. Infracțiunea de violare a vieții private - o noutate în legislaţia penală din România [The offense of violation of privacy - a novelty in the criminal legislation of Romania]. Revista Dreptul, No. 10, 2013, p. 87. 
consent ${ }^{13}$. In practice, numerous situations have been identified when former partners, pursuing revenge, have published on social networks the pictures of their victim in indecent situations, taken with their consent during the relationship. In such a situation, despite the fact that this manner of committing the deed is equally invasive and undoubtedly affects the victims and their mental freedom, the deed is an offense only when the picture has been taken without the victim's consent. If one accepts this thesis, the distribution of pictures taken by the injured party by themselves, even if their publication would affect that party's private life, does not entail criminal liability.

The recent practice, however, is of a different opinion, considering that the phrase used by the legislator, "without right", should not be restricted only to the origins of a picture or recording, because it concerns the overall action of violating privacy. Thus, even if the author of the photograph or of the recording had the consent of the injured party to photograph them at the time, respectively, to record images of them, but for purposes other than that the public presentation or dissemination to third parties, the former will not be able to dispose of those materials at will, transmitting or posting them on various social networking sites.

In a contrary opinion, it is shown that when a person gives his/her consent to be registered, "the condition of typicality of the deed will be removed, the person recorded being in a situation of de culpa in eligendo of the conversation partner" ${ }^{14}$. By accepting such a hypothesis, we appreciate that we might overly deviate from the legislator's intention to provide, above all, criminal protection of the mental security of the person, the social value protected being the right to privacy of a person, the freedom of the person to live according to their own free will inside a private space ${ }^{15}$.

On the contrary, the above considerations do not apply to a phone call made using the "speaker" function of the telephone. We appreciate that such conversation cannot be classified as a private one, since, when activating the speaker button, on one's own initiative, that person has assumed the risk of being heard by other people who might be around. In this case, the tacit consent of the person being listened to will remove the condition of typicality of the deed.

In 2016, the High Court of Cassation and Justice argued that the use of Facebook for the purpose of discrediting a person entails the criminal liability, Facebook being considered as a public space ${ }^{16}$. In a recent jurisprudential decision, it was appreciated that transmitting a compromising record through WhatsApp, when the said transmitting was done without the consent of the injured party,

13 Vasiu I. Infracțiuni ce aduc atingere domiciliului şi vieții private [Offenses affecting the home and private life]. In: Explicațiile noului Cod penal [Explanations of the new Criminal Code], Antoniu G., Toader T. (coord.), Vol. III. Universul Juridic Publishing House, 2015, pp. 263-264.

14 David G., Jebelean M. Violarea vieții private in noul Cod penal (I) [Violation of privacy in the new Criminal Code]. Caiete de drept penal, 2012, No. 3, p. 65.

15 In this respect, Mureşan A. Violarea vieții private în noul Cod penal (II) [Violation of privacy in the new Criminal Code]. Caiete de drept penal, No. 3, 2012, p. 76.

16 Judgment of High Court of Cassation and Justice. Decision No. 4546/2016 of 27.11.2016. Available at: http://www.scj.ro, [last viewed September 27, 2019]. 
encompasses the constitutive elements of the offense of violation of privacy ${ }^{17}$. By transmitting the message to a third party, the right to the inviolability of the injured party's privacy was violated.

The essential requirement for the existence of the crime is the violation of privacy. The European Court of Human Rights has established in its case law that, although the Convention does not expressly guarantee it, the right to reputation is part of the notion of "private life" as enshrined in Article 8 of the Convention ${ }^{18}$.

Regarding publication of pictures with public persons caught in public, the Romanian legislation is quite permissive, as long as the pictures are not taken in private spaces, and are free from offensive or other connotations. So far, we have not found a practical solution that deals with the crime of violation of privacy committed by publishing materials about public persons.

Another common situation in Romania was the supervision of the online activity of employees, respectively, of the correspondence carried out by them with persons with whom they did not necessarily have a professional connection. In a request addressed by the national courts and rejected by them as unfounded, a former employee complained that he was monitored by his employer, who recorded his real-time communications from Yahoo Messenger. The national courts held that "the right of the employer to monitor their employees at the workplace as concerns the use of the company computers is confined into the broad sphere of the notion of control over the way an employee performs his/her tasks", invoking the provisions of Article 40 of the Labour Code. The national courts also showed that as long as it was proved that the employees had been alerted about this possibility, as well as about the employer's right to fire the employees if they were to use the computer for personal purposes, the dismissal is legal.

Nonetheless, the E.C.H.R. condemned Romania and pointed out that those communications of the applicant at the workplace were covered by the concepts of "private life" and "correspondence". As a result, the provisions of Article 8 of the Convention were applicable ${ }^{19}$. The European Court of Human Rights assimilated the correspondence carried out on professional premises with that carried out at home.

\section{Harassment}

Another new regulation introduced in the Romanian legislation is the offense of harassment.

According to Article 208 of the Penal Code, harassment consists in

17 Judgment of Court of Appeal Braşov, Criminal Section. Decision No. 612/2018 of 11.10.2018. Available at: https://lege5.ro [last viewed September 27, 2019].

18 E.C.H.R., Judgment of 20 December 2011 in the case Bălăşoiu v. Romania (application No. $17232 / 04$, pct. 30 ).

19 E.C.H.R, Judgment of 5 September 2017 in case Bărbulescu v. Romania (application No. 61496/08, pct.73). 
the act of an individual who repeatedly, with or without a right or legitimate interest, pursues an individual or supervises their domicile, working place or other places attended by the latter, thus causing them a state of fear, as well as the making of phone calls or communications through remote communication devices which, through their frequency or content, cause a state of fear to an individual.

The incrimination of harassment in the new Penal Code was preceded by numerous cases in practice in which different persons, especially women, were tracked in public places or harassed through messages transmitted over the telephone or through social networks, all of which are of a nature affecting their mental freedom.

The offense apparently sanctions acts without a criminal character, but their repetitive and harassing nature has caused the legislator to incriminate them. The specificity of the act consists of repeated harassment actions, and the perpetration of a single action or isolated actions cannot lead to entailing of the harassment offense, since the typicality requirement is not being fulfilled.

The offense mainly affects freedom and only in a subsidiary manner the private life, but, in some ways, the harassment to a greater extent affects the private life than the freedom of a person.

Thus, the manner of the supervision of a person, of the transmission of private or even public messages on social networks, constitutes an intrusion into the private life of a person, which is likely to affect his or her mental freedom or reputation. The surveillance acts, the messages of a harassing nature may cause a person a psychological discomfort, an alarm and not an effective fear that in the future she will be the victim of a crime, in which case the act would meet the conditions for the offense of threat.

In practice, it has been shown that the supervision of a person and the photographing of such person in public places for the purpose of harassment meet the constitutive elements of the offense of harassment. In this context, the offense of harassment completes the content of the offense of violation of privacy by protecting the dignity of a person, when the photographing or filming of the respective person takes place "without right" in a public place ${ }^{20}$.

By strictly interpreting the text of the law, we would be tempted to state that only actions such as surveillance, following a person or making telephone calls or communications by means of transmission at the distance would meet the constitutive elements of a crime. In fact, these actions can be supplemented with other types of actions that cause a mental discomfort or unnecessary inconveniences to a person ${ }^{21}$. Thereby, the legislator provides the same protection for the fundamental right to private life also when its violation takes place in public spaces or in institutions where the victim carries out his/her activity. The specialized literature includes

20 Judgment of Court of Craiova, Penal Section. Decision No. 1995/2019 of 24.06.2019. Available at: https://lege5.ro [last viewed September 25, 2019].

21 Neagu N. Infracțiuni contra persoanei [Offences against the person]. In: Noul Cod penal comentat [Commentaries on the new Criminal Code], Dobrinoiu V. and collab. Bucharest, Universul Juridic Publishing House, 2012, p. 118. 
in the category of acts of harassment also the acts of destruction, vandalization of some of the victim's property, even killing of their pets ${ }^{22}$. The practice associated to the bullying/harassing actions indicated above also includes actions like publication of a picture, to which a suggestive image has been attached, such as a picture of a trash $\operatorname{bin}^{23}$. The association of images has aroused a wave of comments in the online environment, most of them vulgar and denigrating, which has affected the person's honour and reputation.

Another situation, common in practice, is the harassment of employees in the workplace in order to cause them to resign ${ }^{24}$. They are subjected to harassing, degrading behaviour with a persecutory purpose, capable of instilling in the employee a state of humiliation and inferiority compared to the other employees. The psychological pressures of the employer are capable of exercising a psychological violence against the person, just like the acts which meet the constitutive elements of the offense of violation of the private life. In the category of degrading behaviour, another court includes actions such as the isolation of the employee, preventing the fulfilment of the tasks of the service or the assignation of tasks other than those stipulated in the job description, with the purpose of deprofessionalizing the employee and making his activity "to be sidelined" 25 .

\section{Violation of the professional headquarters}

The new Romanian Penal Code also stands out through the distinct incrimination of the crime of violation of the professional headquarters, since, according to the case law of the European Court of Human Rights, the headquarters of the legal person or the professional establishment of the natural person benefit from the protection conferred by Article 8 of the Convention.

According to Article 225 of the Penal Code, it constitutes an offense

unlawfully entering, in any way, any of the offices/headquarters where a legal entity or a natural person carries out their business or the refusal to leave them upon the request of the entitled person.

So far, in practice, few convictions have been passed strictly for this offense, the crime of violating the professional headquarters being absorbed into the crime of theft, which absorbs in its constitutive content, as aggravating circumstance,

22 Nițu D. Unele considerații privind infracțiunea de hărțuire introdusă de noul Cod penal [Some considerations regarding the crime of harassment introduced by the new Criminal Code]. Caiete de Drept penal, No. 1, 2011, p. 127.

23 Judgment of Court of Balș. Decision No. 640/2019 of 11.07.2019. Available at: https://lege5.ro [last viewed September 25, 2019].

24 Judgment of Court of Appeal Piteşti, Civil Section I. Decision No. 2806/2019 of 12.06.2019. Available at: https://lege5.ro [last viewed September 26, 2019].

25 Judgment of Court of Appeal Bucharest, Civil Section III. Decision No. 573/2019 of 02.07.2019. Available at: https://lege5.ro [last viewed September 25, 2019]. 
the offense of violation of the professional headquarters stipulated in Article 225 of the Penal Code.

The offense of violating the professional headquarters is a crime threatening the current professional activity. Even so, in the case law it was appreciated that even during the night, when the operations of the legal person mostly cease, the space destined to operations of legal person does not cease to constitute a professional office.

The legislator did not limit the notion of professional headquarters to that of social headquarters, professional headquarters designating any point of work where a legal person carries out its activity.

The act of entering a store which is open to public does not constitute the offense of violation of the professional headquarters, since in this case one presumes the existence of a consent from the person to whom the headquarters belong, the latter accepting the breach of the inviolability of the headquarters by the nature of the activity carried out.

\section{Disclosure of professional secrecy}

The offense of disclosure of the professional secrecy was also regulated in the previous Penal Code. The new Penal Code only reformulates it, clarifying its scope by introducing the phrase "private life". Thus, according to Article 227 of the Penal Code, the offense consists in "the disclosure, without right, of data or information regarding the privacy of an individual, which might bring harm to an individual, by someone who has knowledge thereof by virtue of profession or office, and who has the obligation to maintain the confidentiality of said data".

In recent years, many political figures have been subjected to real media outrage during the criminal proceedings against them. The Romanian media, in possession of information about those persons' or their families' private lives, carried out a campaign to denigrate them, before the court ruled on their guilt. The E.C.H.R. sanctioned Romania for the lack of guarantees of the right to respect one's private life. In the case Cășuneanu v. Romania ${ }^{26}$, the Court pointed out that, in domestic law, "the condition of maintaining the confidentiality of the criminal file during the investigations is mainly meant to protect the prosecutors in their efforts to collect evidence and not the accused". As a result, the publication of excerpts from a defendant's telephone calls during criminal proceedings, prior to commencement of the adversary proceedings, is likely to affect the right to respect for his/her private life.

Another common situation in the media is the disclosure of information regarding a person's medical history. The national courts ${ }^{27}$, with express reference to

26 E.C.H.R., Judgment of 16 April 2013 in the case Cășuneanu v. Romania (application No. 22018/10).

27 Judgment of Court of Appeal Bucharest, Civil Section III. Decision No. 535/2015 of 28.04.2015. Available at: https://lege5.ro [last viewed September 30, 2019]. 
the decisions of the E.C.H.R., have shown that the information regarding the health of a person is confined under the notion of "private life", within the meaning of Article 8 of the European Convention on Human Rights. Prohibiting the disclosure of such information not only protects the privacy of some people, but also defends their confidence in the medical staff and health services in general.

Thus, the novelty consists in providing for the obligation not to disclose information obtained on a confidential basis, as a result of the profession, and which is capable of affecting a person's private life. The previous regulation provided the same obligation, not to disclose information obtained by virtue of the profession if "such information is capable of harming a person".

The new Penal Code expressly stipulates that the data or information provided must concern the private life of a person. Thereby, the legislator narrows the scope of the possible perpetrators of the offense of disclosure of the professional secrecy to persons who directly hear the information from the injured party through their confession, such as the lawyer or the priest or those who discover it by virtue of their profession, such as the doctor. The right to privacy is fundamental not only for the protection of a person's private life, but also taking into account the confidence entrusted in institutions or their representatives, by affecting the reputation of a certain profession.

The disclosure of data of a different nature, such as office secrets, is subject to separate incriminations, in the chapter concerning office offenses.

\section{Provisional protection order}

The Romanian legislator has also provided, starting with the year 2018, an adequate procedure for the immediate protection of a person's life, namely, the provisional protection order.

According to Article $22^{1}$ point (1) of Law No. $217 / 2003^{28}$, introduced by means of Law No. 174/2018 ${ }^{29}$, the provisional protection order

is issued by members of the police, who, in the exercise of their duties, find that there is an imminent risk that the life, physical integrity or freedom of a person might be endangered by an act of domestic violence, in order to reduce such risk.

By the provisional protection order, the police officer is entitled to impose protective measures for a period of 5 days to prevent perpetration of a crime, when they find out that there is an imminent risk thereof.

28 Law No. 217/2003 for the prevention and combating of domestic violence. Official Journal of Romania, Part I, No. 367 of 29 May 2003.

29 Law No. 174/2018 regarding the modification and completion of Law No. 217/2003 for the prevention and combating of domestic violence. Official Journal, Part I, No. 618 of 18 July 2018. 
Until 2018, the protection could intervene only as a result of difficult and, in the short term, inefficient civil procedures or as a result of a conviction, when the criminal court ordered a complementary punishment.

Until the regulation of the provisional protection order, Law No. 217/2003 for prevention and combating of domestic violence sustained the possibility of establishing a protection order ${ }^{30}$ issued by the civil court for a maximum period of 6 months. Even if the request for issuing an order is considered with emergency, the procedure before the court is quite cumbersome, which causes the victim to withdraw their request, either out of fear of the perpetrator or because, apparently, the acts of violence against them have ceased.

Furthermore, when the nature of the offenses demands such an intervention, the criminal court may order a complementary sentence in addition to the main penalty, such as the prohibition of being in certain localities, the prohibition of being in certain places, the prohibition to approach the victim's home or work place or the prohibition to communicate with the victim or their family members. The execution of such complementary sentences starts from the moment when the conviction becomes final. Even if these measures can be taken regardless of the nature of the main punishment, we consider that they are not able to provide an early protection of the private life in the case of a person found in imminent danger of being attacked.

The provisional procedure regulated in 2018 is ordered and put into execution by the police forces and has an immediate applicability. The institution is complementary to criminal law and is essentially of a civil nature, but it is connected to acts having a criminal nature and is capable of protecting the victim.

\section{Conclusions}

The incrimination of the actions that affect the private life is an absolute novelty for Romania. The intervention of the legislator was necessary, yet not sufficient. Concepts such as "private life", "private space" are dynamic concepts, and restrictive interpretations of these terms in a society in perpetual motion and technological development might lead to an impermissible limitation of the protection offered by law.

If the term of dwelling, used by the legislator in the incriminations analysed above would be interpreted rigidly, limiting it to the space where an individual spends his/her private life, the violation of private life would be almost non-existent, given that a person spends less and less time at home. Privacy cannot be restricted exclusively to a person's dwelling, but must be extended to any place, where a person expects not to be seen by others.

Although the legislator aspired to offer protection of this right also in the case where the action takes place in public spaces or in those spaces where a person

30 Article 23 of Law No. 217/2003. 
carries out his/her professional activity, such an interpretation should be explicitly derived from the text of the law, so as not to allow any room for interpretations or to leave unsanctioned anti-social actions which are as dangerous as those perpetrated inside a dwelling.

By limiting the scope of the aforementioned offenses to definite spaces, to certain anti-social behaviours or to particular social contexts, we risk losing sight of what is actually desired by means of these regulations, namely, the criminal protection of a person's mental safety and reputation.

\section{BIBLIOGRAPHY}

\section{Literature}

1. Chiriță R. Convenția europeană a drepturilor omului. Comentarii şi explicații [European Convention on Human Rights. Commentaries and explanations]. Vol. II: C. H. Beck, 2007.

2. David G., Jebelean M. Violarea vieții private în noul Cod penal (I) [Violation of privacy in the new Criminal Code]. Caiete de drept penal, No. 3, 2012.

3. Neagu N. Infracțiuni contra persoanei [Offences against the person]. In: Noul Cod penal comentat [Commentaries on the new Criminal Code], Vasile Dobrinoiu and collab. Bucharest, Universul Juridic Publishing House, 2012.

4. Nițu D. Unele considerații privind infracțiunea de hățuire introdusă de noul Cod penal [Some considerations regarding the crime of harassment introduced by the new Criminal Code]. Caiete de Drept penal, No. 1, 2011.

5. Mureşan A. Violarea vieții private în noul Cod penal (II) [Violation of privacy in the new Criminal Code]. Caiete de drept penal, No. 3, 2012.

6. Slăvoiu R. Infracțiunea de violare a vieții private - o noutate în legislația penală din România [The offense of violation of privacy - a novelty in the criminal legislation of Romania]. Revista Dreptul, No. 10, 2013.

7. Vasiu I. Infracțiuni ce aduc atingere domiciliului şi vieții private [Offenses affecting the home and private life]. In: Explicațiile noului Cod penal [Explanations of the new Criminal Code], Vol. III, Antoniu G., Toader T. (coord.), Universul Juridic Publishing House, 2015.

\section{Legislative acts}

1. Law No. 217/2003 for the prevention and combating of domestic violence. Official Journal of Romania, Part I, No. 367 of 29 May 2003.

2. Law No. 278/2006 regarding the modification and completion of the Penal Code. Official Journal, Part I, No. 601 of 12 July 2006.

3. Law No. $174 / 2018$ regarding the modification and completion of Law no. 217/2003 for the prevention and combating of domestic violence. Official Journal, Part I, No. 618 of 18 July 2018.

\section{Legal practice: international}

1. E.C.H.R, Judgment of 20 December 2011 in case Bălăşoiu v. Romania (application No. 17232/04). 
2. E.C.H.R., Judgment of 19 November 2013 in case Ulariu v. Romania (application No. 19267/05).

3. E.C.H.R., Judgment of 16 April 2013 in case Cășuneanu v. Romania (application No. 22018/10).

\section{Legal practice: national}

1. Constitutional Court of Romania, Decision No. 33/2017 regarding the rejection of the challenge of unconstitutionality of the provisions of Article 226 para. (1) of the Penal Code. Official Journal, Part I, No. 320 of 4 May 2017.

2. Judgment of Court of Appeal Bucharest, Civil Section III. Decision No. 535/2015 of 28.04.2015.

3. Judgment of High Court of Cassation and Justice. Decision No. 4546/2016 of 27.11.2016.

4. Judgment of Court of Appeal Braşov, Criminal Section. Decision No. 612/2018 of 11.10.2018.

5. Judgment of Court of Craiova, Penal Section. Decision No. 1995/2019 of 24.06.2019.

6. Judgment of Court of Balș. Decision No. 640/2019 of 11.07.2019.

7. Judgment of Court of Appeal Piteşti, Civil Section I. Decision No. 2806/2019 of 12.06.2019.

8. Judgment of Court of Appeal Bucharest, Civil Section III. Decision No. 573/2019 of 02.07.2019. 